Новиков А. $О$.

доктор філологічних наук, професор Глухівський наџіональний педагогічний університет ім. О. Довженка

\title{
УКРАИНА В ТВОРЧЕСКИХ ЗАМЫСЛАХ АЛЕКСАНДРА ГРИБОЕДОВА
}

У статті йдеться про те, щчо основна мета поӥздки Олександра Грибоєдова до Києва і Криму влітку 1825 року була пов'язана швидше за все не з декабристськими справами, про щчо твердять деякі дослідники, а з бажанням зібрати матеріал для нових художніх творів, в основі яких мали бути сюжети з історії Украӥни.

Ключові слова: подія, сюжет. 
В статье говорится о том, что основная цель поездки Александра Грибоедова в Киев и Крым летом 1825 года скорее всего была связана не с декабристскими проблемами, на чем настаивают некоторые исследователи, а с желанием собрать материал для новых художественных произведений, в основе которых должны были быть сюжеты на исторические темы.

Ключевые слова: события, сюжет.

This article is about that the main purpose of Aleksandr Griboedov's journey to Kyiv and Crimea in summer in 1825 was related probably not to decembrist businesses, what some researchers assert about, but with a desire to collect material for new artistic works in basis of which there must be episods from the history of Ukraine.

Key words: episods, plot.

Летом 1825 года, в самый разгар декабристского движения, А. С. Грибоедов предпринял поездку в Киев и Крым. В научной литературе не существует единой точки зрения относительно цели этой поездки. М. В. Нечкина, например, уверена, что во время путешествия на юг автор «Горя от ума» выполнял поручения декабристов, что его встреча с членами Южного общества имела вполне определенное назначение - связаться с генералом Ермоловым [Нечкина 1977: 520, 530]. Совершенно иного мнения придерживается Н. К. Пиксанов, который считает, что Грибоедов тогда «был очень далек от политических интересов» [Пиксанов 1911: LIX].

Таким образом, предстоит выяснить причины, побудившие поэта совершить этот вояж за несколько месяцев до декабрьского восстания. К лету 1824 года, когда Грибоедов после продолжительного отсутствия вернулся в Петербург, комедия «Горе от ума» была завершена в новой и окончательной редакции. Изменения, вносившиеся в текст в последующее время, принципиального значения уже не имели. Вполне логичным было бы предположить, что примерно тогда же перед писателем могла возникнуть проблема поиска сюжетов для новых произведений. Прецедент уже был. Осенью 1823 года, когда «Горе от ума» было закончено в первой редакции, он сначала взялся за работу над «Юностью вещего», а затем вместе с Вяземским написал оперу-водевиль «Кто брат, кто сестра». Надо полагать, драматург отдавал себе отчет в том, что 
подобные сочинения не соответствовали уровню его таланта. Недаром ведь несколько позже в одном из его писем проскользнет высказывание о «беспредельных» творческих планах [Грибоедов 1917: 178]. Материал для новых произведений Грибоедов, как и многие его современники, собратья по перу (например, Рылеев, Глинка, Сомов), искал в историческом прошлом Украины. Подготовительная работа, которую поэт проделал в связи с поездкой в Киев и Крым, вопросы, интересовавшие его в процессе самого путешествия, свидетельства современников, наконец, творческие заготовки являются убедительным тому подтверждением.

Задумав поездку в Украину, Грибоедов заранее стал к ней готовиться, свидетельством чему есть небольшая тетрадка его заметок «Desiderata», которая в составе так называемой «Черновой тетради» впервые была опубликована Д. А. Смирновым в 1859 году. Страницы ее буквально испещрены ссылками на источники, из которых автор черпал интересующую его информацию. По мнению Н. К. Пиксанова, эту тетрадь писатель начал создавать, возможно, еще в 1824 году, подобно тому, как он стал «изучать Персию раньше отъезда туда». Хотя вполне очевидно, подчеркивает исследователь, что продолжать свои записи Грибоедов мог и в процессе самого путешествия. Нельзя не согласиться также с утверждением ученого, что многие записи драматурга имеют непосредственное отношение ко всему его пути в Крым и путешествию по полуострову [Грибоедов 1917: 301, 302].

Анализ проработанной Грибоедовым литературы позволяет сделать вывод о том, что это были, как правило, тщательно подобранные сочинения и справочники русских и зарубежных авторов, по которым можно было изучать Украину и прилегающие к ней области в историческом, географическом и культурном аспектах. Это, например, «Путешественные записки от Петербурга до Херсона» В. Ф. Зуева, «Летопись русская с Воскресенского списка», «Книга Большому Чертежу в списке 1627 г.», «Слово о полку Игореве», «История Российская» В. Н. Татищева, «Словарь Географи- 
ческий Российского Государства» Максимовича и Щекатова, сочинения Гильденштедта, Палласа, Фалька и т. д. Особый интерес представляют книги, обнаруженные в походной библиотечке поэта во время обыска в январе 1826 года. Кроме «Путешествия по Тавриде в 1820 г.» (СПб., 1823) И. М. Муравьева-Апостола, известного по ссылкам в рабочей тетради, здесь оказались «Описание Киево-Печерской лавры, краткое описание Киева, < ..> старинные малороссийские песни, киевские святцы...» [ГВС 1929: 149]. Известно также то, что, находясь под арестом на гауптвахте Главного штаба, Грибоедов просил Булгарина передать ему «Тавриду» Боброва, то есть «Тавриду, или Мой летний день в Таврическом Херсонесе. Лирико-эпическое песнопение, сочиненное капитаном С. Бобровым» (Николаев, 1798) [Грибоедов 1917: 192, 338-339].

Как видно из содержания «Путевых записок» и «Desiderata», Грибоедов прекрасно знал историю и культуру Украины с древнейших времен. По хронологии это охватывает период, начиная с восточнославянского единства по 1820-е годы включительно. Например, наличие в «Черновой тетради» цитат из «Повести временных лет» свидетельствует о том, что автор «Горя от ума» основательно изучил древний шедевр [Грибоедов 1917: 77]. А это и легенда об основании Киева, и рассказы о первых киевских князьях, и крещение киевлян, и многое другое. Судя по заметкам на страницах «Desiderata» [Грибоедов 1917: 96-97, 100], поэт также внимательно читал сочинение французского инженера XVII столетия Гильома Левассера де Боплана «Описание Украйны», где весьма обстоятельно рассказывается о жизни, традициях и обрядах украинского народа. Особо пристальное внимание уделял Грибоедов тем страницам «Описания Украйны», на которых повествуется об образе жизни и нравах запорожских казаков [Грибоедов 1917: 100].

Большое значение придает автор «Горя от ума» также описанию Бопланом днепровских порогов и островов, подтверждением чему является наличие в «Черновой тетради» пространных ци- 
тат из «Описания Украйны» (кстати, на языке оригинала - французском). Вместе с тем некоторые утверждения французского инженера Грибоедов подвергает сомнению. «Лучшие карты, - отмечает он, - не показывают никакого острова поперек Стрельчего порога, что по ошибке Боплан относит к сему порогу утесистые острова, которые находятся на Лоханском пороге» [Грибоедов 1917: 97].

С такой же научной скрупулезностью подходит Грибоедов и к высказыванию В. Ф. Зуева о том, что Будильский порог следует относить к большим. Ведь «он его сам не посещал» [Грибоедов 1917: 97], - не без оснований замечает поэт, у которого была возможность сравнить описание днепровских порогов по нескольким источникам (например, по «Описанию Украйны» и «Книге Большому Чертежу...»).

Находясь в Севастополе, Грибоедов посетил древний Корсунь (Херсонес). События, связанные с этим античным городом, имели, как известно, отношение к принятию Владимиром решения о введении на Руси христианства. В том памятном 988 году великий князь со своей дружиной взял Корсунь в осаду. Готовясь к штурму, он приказал воинам присыпать насыпь к городским стенам. На это «корсуняне, - цитирует писатель Нестора-летописца, подкопавше стену крядаху сыплемую персть и ношаху себе в град, сыплюще посреде града и воины Владимировы присыпаху более» [Грибоедов 1917: 77]. И только хитрость киевского князя (лишение корсунян воды) позволила ему овладеть городом. По условию мирного договора с византийскими царями Василием и Константином Владимир мог жениться на их сестре Анне. Однако перед этим он должен был креститься, что и было сделано. В честь этого знаменательного события на том месте, где корсуняне ссыпали землю, построили церковь, которая, как гласит летопись, «стоит $u$ до сего дни» [ЛВС 1856: 310].

Церковь эта, как и многие другие строения города, конечно же, не сохранилась, и Грибоедов пытается определить хотя бы то место, 
где она стояла. «К сей стороне, внутри, насыпной холм, - размышляет писатель. - Не здесь ли Владимир построил церковь?» Отсюда «все видно, что происходит в древнем Корсуне и приступ легок». Автор «Горя от ума» приходит в восторг от одной только мысли, что «может, Великий Князь стоял на том самом месте», где он теперь - «между Песочной и Стрелецккой бухты»»[Грибоедов 1917: 77].

Очень важные события (во многом трагические) развернулись в Киеве после возвращения туда Владимира. Князь велел своим подданным принять новую христианскую веру. Притом идолов, которых на протяжении веков почитали на Руси за богов, он приказал уничтожить, а главного, Перуна, сбросить в Днепр, протащив перед тем привязанным к хвосту коня и поколотив «на поруганье бесу» палками. Многие «неверные», отмечает летописец, оплакивали своего бога. Место же, где за порогами Перуна прибило к берегу, стали с тех пор называть Перуня рень (Перунья отмель) [ЛВС 1856: 311$]$.

Характерно, что и это событие не осталось без внимания Грибоедова. Так, в «Черновой тетради» читаем: «Есть ли залив (или заводь) Днепра, бухта, ниже порогов, известная Перуня рень?» [Грибоедов 1917: 96]. Возник этот вопрос, надо полагать, отнюдь не случайно. В его основу заложен давний и глубокий интерес поэта к старине - народным поверьям, традициям, обрядам.

Столь пристальное внимание Грибоедова к событиям более чем 800-летней давности обусловлено, конечно же, его творческими замыслами. По словам А. Н. Муравьева, Грибоедов собирался написать трагедию о князе Владимире [Голубов 1939: 4]. Весьма примечательно, что о своем увлечении этой неординарной личностью он упоминал летом 1825 года в письме к В. Ф. Одоевскому [Грибоедов 1917: 175].

Другой не менее интересной эпохой, которая привлекала внимание Грибоедова, был период феодальной раздробленности. Данной теме посвящено восемь дезидерат. В эпицентре внимания 
поэта многолетняя борьба за киевский престол сына Владимира Мономаха Юрия Долгорукого со своим племянником князем Изяславом Мстиславичем. Шла эта тяжба с переменным успехом. И нередко чаша весов склонялась на ту или иную сторону в зависимости от степени вмешательства в противоборство других удельных князей, главным образом родственников, а также венгров, поляков, болгар и особенно половцев, которые, пользуясь ситуацией, разоряли разобщенные русские земли, угоняли в рабство их жителей.

Изучавшиеся поэтом события являются, судя по всему, подготовительным материалом для создания задуманной им драматической поэмы периода борьбы Киевской Руси с половцами, о чем свидетельствует отрывок под названием «Диалог половецких мужей». Есть основания предполагать, что по крайней мере одна из сцен нового произведения должна была происходить в Киеве, в борьбе за который разворачиваются основные события. Весомым аргументом, подтверждающим нашу гипотезу, является пометка автора «Горя от ума» в его дорожном дневнике о необходимости прочесть описание Киева [Грибоедов 1917: 98]. Притом запись эта сделана в ряду других, относящихся к изучаемой эпохе.

Нельзя не обратить внимания и на то, что исторический период, которым столь пристально интересовался Грибоедов, вплотную примыкает к событиям, описанным в «Слове о полку Игореве». В 1820-е годы этот древний литературный памятник пользовался большой популярностью в литературных кругах России. Тот страстный пафос, с которым безымянный автор призывал князей к единению перед лицом грозящей внешней опасности, находил отклик в среде передовой дворянской интеллигенции.

По записям в рабочей тетради видно, что при подготовке к поездке в Украину Грибоедов обращался к «Слову о полку Игореве» [Грибоедов 1917: 100]. Поход князя Игоря интересовал его не только с художественной, но и с научно-исследовательской стороны, свидетельством чему является факт изучения писателем «Ис- 
торического исследования о местоположении древнего Тмутараканского княжения» А. И. Мусина-Пушкина [Грибоедов 1911: 92]. Можно предположить, что драматург пытался проследить путь Игоря Святославича. Вряд ли случайно взгляд Грибоедова остановился на реке Сальнице [Грибоедов 1917: 95], о которой как о месте жестоких и непримиримых сражений с половцами говорится в «Книге Большому Чертежу» [КБЧ 1838: 30]. Именно на этот источник ссылается писатель. Еще более конкретно о походе в 1185 году, в том числе и о Сальнице, рассказывается в неоднократно цитированной Грибоедовым «Истории Российской» В. Н. Татищева [Татищев 1964: 134].

В некоторых выражениях «Диалога половецких мужей» Н. К. Пиксанов усматривает «влияние «Слова о полку Игореве» [Грибоедов 1911: 300]. Основанием для такого вывода, по мнению Ф. Я. Приймы, ему послужила небольшая заметка Грибоедова о древней поэме: «Къметъ, къмети (сподвижники, слуги, дружина). Не то ли, что Comte, в первоначальном значении? А мои Куряни сведоми къмети» (см. «Слов. о пол. Игореве»). Анализ приведенной выше грибоедовской цитаты [Грибоедов 1917: 100] позволяет Ф. Я. Прийме прийти к заключению, что автор «Горя от ума» был «основательно эрудированным и пронищательным комментатором "Слова о полку Игореве". К примеру, предположение поэта о восхождении старославянского слова "къметь" к латинскому "coтеs" независимо от него, - продолжает исследователь, - спустя столетие появилось в словаре М. Фасмера» [Прийма 1980: 237-238].

В «Черновой тетради» можно найти немало записей, посвященных истории Украины середины XVII столетия. Есть основания предполагать, что Грибоедов готовился к созданию широкого эпического полотна на материале национально-освободительной войны 1648-1654 годов. Серьезным аргументом в пользу данного предположения является заметка поэта о запорожце, в сжатой форме которой сконцентрированы важные сведения о быте, нравах 
и образе жизни украинского казачества [Грибоедов 1917: 100]. Особенно впечатляюще эта гипотеза выглядит на фоне его огромного интереса к «Описанию Украйны» Боплана, подробно повествующем об этом периоде истории нашей страны.

Органичным продолжением изучения Грибоедовым Украины в теоретическом плане была его поездка в Киев и Крым. По мнению М. В. Нечкиной, в Киев поэт приехал 1 или 2 июня 1825 года [Нечкина 1977: 518], и с этим можно согласиться. Первое известное нам киевское письмо Грибоедова (С. Н. Бегичеву) датировано 4 июня. Как видно из этого послания [Грибоедов 1917: 174], и особенно из письма В. Ф. Одоевскому от 10 июня [Грибоедов 1917: 174-176], впечатления от пребывания на украинской земле буквально потрясли автора «Горя от ума». По приезде в Киев он как бы окунулся в глубину веков, чему способствовали многочисленные исторические памятники, давнишняя любовь к старине, хорошее знание прошлого и, конечно же, богатая фантазия поэта. «Сам я в древнем Киеве <...>, - пишет Грибоедов В. Одоевскому. - Владимиры и Изяславы совершенно овладели моим воображением; за ними вскользь заметил я настоящее поколение». И далее, как бы специально желая подчеркнуть свой повышенный интерес к минувшему, драматург выказывает полнейшее безразличие к бушующим мирским страстям: «...Как они мыслят и что творят русские чиновники и польские помещики - Бог их ведает» [Грибоедов 1917: 175]. Грибоедова восхищают и виды Днепра, и «святость развалин», и «мрак пещер», и тополи, и виноградники, и многое другое, «чего нет у нас», как объясняет он сам. Целая гамма чувств охватывает писателя при входе «в темноту Лавры или Софийского собора» [Грибоедов 1917: 175]. Потом, путешествуя по Крыму, он будет сравнивать тамошние красоты с тем, что видел в Киеве. «Спускаюсь к морю. <...> От иеркви глядеть наверх, к колокольне, похоже на Киевскую Лавру, но вид Лавры несравненно лучше», - запишет автор «Горя от ума» в своем дневнике, посетив Севастополь [Грибоедов 1917: 75]. 
Во время пребывания в Киеве Грибоедов жил в «Зеленой гостинице», принадлежащей Киево-Печерской лавре. Одновременно с ним останавливался там и приехавший с Волыни будущий декабрист Артамон Муравьёв с супругой. Встречался писатель здесь и с другими членами Южного общества - С. П. Трубецким, М. П. Бестужевым-Рюминым, Сергеем и Матвеем МуравьёвымиАпостолами [Базилевич 1929: 42]. По мнению М. В. Нечкиной, эти встречи не были случайными. Через Грибоедова декабристы, как уже отмечалось, собирались обратиться за поддержкой к генералу Ермолову. Однако ввиду сомнений поэта «в правильности тактики военной революции» они не смогли договориться [Нечкина 1977: 528-529, 536].

Все это, разумеется, только предположения, и, как справедливо отмечает сам автор гипотезы, «нет, и, по-видимому, и не предвидится в будущем материалов для бесспорных утверждений» [Нечкина 1977: 529].

В Киеве поэт пробыл около двух недель. Во всяком случае известно, что 10 июня 1825 года он был еще в Киеве ${ }^{1}$, а 9 сентября в письме к С. Н. Бегичеву сообщает, что «почти три месяиа <...> провел в Тавриде» [Грибоедов 1917: 177].

Путешествуя по Крыму, автор «Горя от ума» встречался с Н. Н. Оржицким, поэтом и поручиком Ахтырского гусарского полка. Как видно из письма к Бестужеву-Марлинскому от 22 ноября, с Оржицким велись разговоры на острые политические темы, о чем, в частности, свидетельствуют слова: «...Вспомнили о тебе (Бестужеве - А. Н.) и о Рылееве, которого обними за меня искренне, по-республикански» [Грибоедов 1917: 182]. Кроме того, в Симферополе у Грибоедова были контакты с его старыми знакомыми - будущим декабристом М. Ф. Орловым и А. Н. Муравьёвым [Пиксанов 1911: LX]. С последним он, кстати, затем продолжил путешествие по полуострову.

1 Этим числом датировано письмо Грибоедова из Киева В. Ф. Одоевскому. 
Крым Грибоедов исколесил буквально вдоль и поперек - и верхом, и пешком, и в лодке по речкам и заливам. Побывал он в Симферополе, Феодосии, Севастополе, Ялте, Алупке, Симеизе, Бахчисарае и многих других местах, в том числе труднодоступных пещерах и на вершинах гор, откуда любовался морем. Свои впечатления драматург заносил в «Путевые записки», делился ими в письмах с друзьями [Грибоедов 1917: 68-82, 176-181]. «...Здесь природа против Кавказа все представляет словно в сокращении $<\ldots>$, - напишет он, например, 9 июня 1825 года С. Н. Бегичеву. Зато прелесть моря и иньх долин, Качи, Бельбека, Касипли - Узеня и проч., ни с чем сравнить не можно» [Грибоедов 1917: 176-177].

Вместо запланированных трех недель, или даже «того менее» [Грибоедов 1917: 176], Грибоедов провел в Крыму почти три месяца. По словам М. Орлова, он был «без ума» от этого цветущего края [Медведев 1956: 493].

Нельзя не обратить внимания на то, что некоторые грибоедовские заметки содержат в себе элементы неосуществленных творческих замыслов. Вот как, например, поэт описывает летний крымский вечер: «Солнце заходит в море, и черное облако затемняет часть его; остальная в виде багрового серпа месяча. Худое знамение для варягов» [Грибоедов 1917: 77]. Нет сомнений в том, что, путешествуя по Крыму, Грибоедов обдумывал сцены трагедии из жизни Киевской Руси конца Х столетия. Чем бы он ни занимался, его мысли то и дело возвращаются к личности князя Владимира. «NB. Воспоминание о к. Владимире»- находим запись в «Путевых записках» [Грибоедов 1917: 75]. И подобных заметок в «Черновой тетради» можно найти немало. Особенно много высказываний на эту тему появилось у Грибоедова после посещения им развалин древнего Корсуня.

Разделяя в целом позицию Н. К. Пиксанова, что изучению истории и археологии Крыма Грибоедов придавал большое значение, мы все же не можем согласиться с ученым, когда он утверждает, что крымские древности интересовали писателя «гораздо 
более, чем местные жители» [Пиксанов 1911: LX]. Как свидетельствуют современники, драматург изучал, например, родословную татар Альбугази [ГВС 1929: 150]. На страницах «Путевых записок» высказываются замечания относительно некоторых особенностей в лицеочертании «приморских татар». Притом собственные наблюдения Грибоедов, как и в большинстве других случаев, сравнивает с высказываниями авторитетных ученых. В данном случае таковым является академик Паллас [Грибоедов 1917: 74].

Весьма примечательно, что, встречаясь с аборигенами в гоpax, автор «Горя от ума» обратил внимание на нетипичность их внешнего вида, в связи с чем с присущей ему эрудицией исследователя отметил: «У здешних пастухов лища не монгольские и не туречкие. Паллас производит их от литургийщев и греков, но они белокуры, черты северные, как у осетинов на Кавказе» [Грибоедов 1917: 69].

Не ускользнуло от внимания Грибоедова также то обстоятельство, что татары очень бедны [Грибоедов 1917: 74], а «цыганская нынешняя музыка в Крыму смесь татарского с польским и малороссийским» [Грибоедов 1917: 69]. Такие примеры в творческом и эпистолярном наследии писателя далеко не единичны.

Подводя итог, нельзя не прийти к выводу о том, что основная цель поездки Грибоедова в Киев и Крым была обусловлена его глубоким интересом к Украине. Все остальные мотивы (если они имели место) были второстепенны. Нет достаточных оснований связывать его с чисто декабристскими мотивами, как это делает М. В. Нечкина. Тем не менее нельзя согласиться и с утверждением Н. К. Пиксанова, что в то время Грибоедов был очень далек от политических интересов. Данное суждение не согласуется ни с тем авторитетным положением, которое автор «Горя от ума» занимал в декабристских кругах, ни с некоторыми его довольно откровенными высказываниями, звучавшими явным диссонансом по отношению к официальной идеологии. 
К путешествию в Киев и Крым Грибоедов стал готовиться задолго до лета 1825 года. Украина привлекала его прежде всего богатым историческим прошлым, уходящим своими корнями в глубокую древность. Подобно писателям-декабристам, украинский материал поэт собирался использовать для создания новых произведений. Можно предположить, что таких произведений должно было быть как минимум три. Это трагедия о князе Владимире, драматизированная поэма на тему противоборства Киевской Руси с половцами накануне монголо-татарского нашествия («Диалог половецких мужей»- дошедшая до нас часть задуманного сочинения) и широкое эпическое полотно, посвященное национально-освободительной войне 1648-1654 годов.

\section{БИБЛИОГРАФИЯ}

ГВС 1929 - А. С. Грибоедов в воспоминаниях современников. - М. : Федерация, 1929. $-344 \mathrm{c}$.

Базилевич 1929 - Базилевич В. М. Грибоедов в Киеве. - К. : Автор, 1929. - 8 с. Голубов 1939 - Голубов С. А. Н. Муравьёв об А. С. Грибоедове // Литературная газета. $-1939 .-20$ авг.

Грибоедов 1911 - Грибоедов А. С. Полное собрание сочинений. - Пг., 1911. T. $1 .-328 \mathrm{c}$.

Грибоедов 1917 - Грибоедов А. С. Полное собрание сочинений. - Пг., 1917. T. 3. $-396 \mathrm{c}$.

КБЧ 1838 - Книга Большому Чертежу или древняя карта Российского государства, поставленная в разряде и описанная в книгу 1627 года. - 2-е изд. - СПб., 1838. $-261 \mathrm{c}$.

ЛВС 1856 - Летописи по Воскресенскому списку // Полное собрание русских летописей. - СПб., 1856. - Т. 7. - 345 с.

Медведев 1956 - Медведев М. М. Новое о Грибоедове и декабристах // Литературное наследство. - Т. 60: Декабристы-литераторы. - М. : АН СССР, 1956. Кн. 1. - С. 475-496.

Муравьёв-Апостол 1820 - Муравьёв-Апостол И. М. Путешествие по Тавриде в 1820 году. - СПб., $1823 .-337$ с.

Нечкина 1977 - Нечкина М. В. Грибоедов и декабристы. - М. : Художественная литература, 1977. - $735 \mathrm{c.}$

Пиксанов 1911 - Пиксанов Н. К. А. С. Грибоедов: (Биографический очерк) // Грибоедов А. С. Полное собрание сочинений. - СПб., 1911. - Т. 1. - С. VCXIVII. 